\title{
EFFECT OF PHEROMONE TRAP DENSITY ON MASS TRAPPING OF MALE POTATO TUBER MOTH Phthorimaea operculella (ZELLER) (LEPIDOPTERA: GELECHIIDAE), AND LEVEL OF DAMAGE ON POTATO TUBERS
}

\author{
Patricia Larraín S. ${ }^{*}$, Michel Guillon², Julio Kalazich³ ${ }^{3}$ Fernando Graña ${ }^{1}$, and Claudia Vásquez ${ }^{1}$
}

\begin{abstract}
Potato tuber moth (PTM), Phthorimaea operculella (Zeller), is one of the pests that cause the most damage to potatoes (Solanum tuberosum L.) in both field crops and storage, especially in regions where summers are hot and dry. Larvae develop in the foliage and tubers of potatoes and cause direct losses of edible product. The use of synthetic pheromones that interfere with insect mating for pest control has been widely demonstrated in numerous Lepidoptera and other insect species. An experiment was carried out during the 2004-2005 season in Valle del Elqui, Coquimbo Region, Chile, to evaluate the effectiveness of different pheromone trap densities to capture P. operculella males for future development of a mass trapping technique, and a subsequent decrease in insect reproduction. The study evaluated densities of 10, 20, and 40 traps ha-1 ${ }^{-1}$, baited with $0.2 \mathrm{mg}$ of PTM sexual pheromone, and waterdetergent for captures. Results indicated that larger numbers of male PTM were captured per trap with densities of 20 and 40 traps per hectare, resulting in a significant reduction $(\mathrm{P}<0.05)$ of tuber damage in these treatments compared with the control which used conventional chemical insecticide sprays.
\end{abstract}

Key words: potato tuber moth, Phthorimaea operculella, mass trapping, pheromone.

\section{INTRODUCTION}

The potato tuber moth is a pest which economically affects potato crops, mainly in regions where the climate is hot and dry. The larvae cause direct damage to the tubers by infesting them underground and control using chemical insecticide sprays is difficult with uncertain results.

The use of synthetic sexual pheromones to interfere with reproduction offers a non-traditional way to manage pest control that does not use insecticides. Sexual pheromones are species-specific and highly selective, and since they are not toxic and do not represent health risks to humans and animals, they are valuable tools in integrated pest control management.

The use of pheromone traps for mass trapping is an insect control method that has been sufficiently

\footnotetext{
${ }^{1}$ Instituto de Investigaciones Agropecuarias, Centro Regional de Investigación Intihuasi, Apartado Postal 36/B, La Serena, Chile. *Corresponding author (plarrain@inia.cl).

International Biocontrol Agent Manufacturers' Association IBMA, 13 Avenue du Béarn, 64000 Pau, France. (guillon.ibma@orange fr). ${ }^{3}$ Instituto de Investigaciones Agropecuarias, Centro Regional de Investigación Remehue, $\mathrm{km} 8$ ruta 5 Norte, Osorno, Chile.

Received: 16 June 2008.

Accepted: 07 December 2008.
}

researched (El-Sayed et al., 2006). It interferes with insect mating, reducing the future larvae population and subsequent damage. In order to improve the effectiveness of the captures and make the traps a more reliable tool in management programs, it is necessary to determine the factors that affect their efficiency (Athanassiou et al., 2002; 2003a; 2003b; 2004; 2005; 2007). Traps can also be used with the degree-day calculation method for decisionmaking on the application of insecticides in pest control (Kumral et al., 2005).

The $P$. operculella pheromone has been studied since 1969 by Adeesan et al. who discovered that it was released from a gland located just before the last abdominal segment of the female. Afterwards, research by Fouda et al. (1975), Roelofs et al. (1975), Persoons et al. (1976), Yamoaka et al. (1976), Bacon et al. (1976), Voerman et al. (1977), Voerman and Rothschild (1978), identified, isolated, and synthesized the two main pheromone compounds, finding that combining them attracted the male moths more than each compound taken separately. Bacon et al. (1976) and Raman $(1982 ; 1984)$ also evaluated the most effective rates of these two compounds in the mixture preparation, as well as some techniques to use these compounds in field and storage traps. 
This pheromone is currently available on the market and is related to the mixture of the trans-4, cis7-tridecadienil1-ol-acetate and trans-4, cis7, cis10 tridecatrienil-1-olacetate compounds in a ratio of $1: 1.5$. This mixture is generally commercialized as a rubber device in which the mixture is impregnated in $1 \mathrm{mg}$ doses.

Though there are some control studies of mass trapping and mating disruption of $P$. operculella (Raman, 1982; 1984; Salas et al., 1985; Ortu and Floris, 1989), these techniques are not used and this pest is mainly controlled with broad-spectrum pesticides.

On the other hand, since there are many factors that can affect the effectiveness of these control methods, it is important to conduct studies that confirm the effectiveness of pheromone use as a control technique for specific crop conditions where the moth constitutes an economically important pest. This explains why the objective of this study was to evaluate the effect of different trap densities on the number of male $P$. operculella captured and the effect of these captures on the reduction of damage caused by larvae in tubers produced under agro-ecologic conditions in the coastal zone of the Coquimbo Region, Chile.

\section{MATERIALS AND METHODS}

During the 2004-2005 season, a massive trapping trial of male potato tuber moth (PTM) was conducted using pheromones in different densities of traps per area. The trial was carried out in El Romero sector (29 53' S; $71^{\circ} 07^{\prime}$ W), La Serena, Coquimbo Region, Chile, using a randomized complete block design with four replications. The area of the experimental plots was $4000 \mathrm{~m}^{2}$.

Sowing took place on 30 October 2004 in an area of approximately 13 ha. Nine hectares were sown with certified daughter seed of the Asterix variety, whereas the remaining hectares were sown with Cardinal potato seed.

The trial was fertilized with $\mathrm{N}, \mathrm{P}_{2} \mathrm{O}_{5}$, and $\mathrm{K}_{2} \mathrm{O}$ in doses of 150,120 , and $60 \mathrm{~kg} \mathrm{ha}^{-1}$, respectively. Mancozeb $1.6 \mathrm{~kg}$ a.i. ha-1 (Mancozeb $80 \%$ WP) fungicide was applied during cultivation to control late blight (Phytophthora infestans). Linuron $1 \mathrm{~kg}$ a.i. ha ${ }^{-1}$ (Linurex $50 \mathrm{WP}$ ) was initially applied to control weeds, but these were later controlled manually. Furrows were irrigated every 7 days. Harvest took place between 31 January and 4 February 2005.

Three trap densities were evaluated with the sexual pheromone of $P$. operculella: trans-4,cis-7-tridecadieno1-ol-acetato and trans-4,cis-7,cis-10 tridecatrieno-1-olacetato in a ratio of $1: 1.5$, and $0.2 \mathrm{mg}$ dose per trap in accordance with the results obtained by Larraín et al. (2007). The trap densities evaluated were 10, 20, and 40 traps ha $^{-1}$ in plots untreated with insecticides. Treatments were distributed within each plot, with $35 \mathrm{~m}$ between plots and a minimum of $5 \mathrm{~m}$ between traps (40 traps ha-1) (Figure 1). These distances were selected in order to avoid the effect between treatments with distinct trap densities, and considering the results of Cameron et al. (2002), who studied the activity of $P$. operculella with entomologic nets and pheromones, finding that adult activity declined at distances of 20 and $40 \mathrm{~m}$ from a release point.

The number of traps used in the trial area corresponding to the 10,20 , and 40 trap ha $^{-1}$ densities were 4,8 , and 16 treatments, respectively, with a total of 112 traps in the trial. The traps were all assembled in the same way as established by Larraín et al. (2007), using 5 L capacity plastic drums containing $2 \mathrm{~L}$ of water with $0.2 \%$ detergent. The dispenser with $0.2 \mathrm{mg}$ of pheromone per trap was supplied by Agrisense-BCS (Pontypridd, South Wales, UK).

\section{Evaluations}

All traps were set up on 6 December 2004. Starting on that date and until harvest, a weekly count checked the number of male moths captured in all the traps of each plot. At that moment, an $80 \mathrm{~kg}$ sample of tubers from a $25-30 \mathrm{~m}^{2}$ area was taken. This sample was taken from the center of each $4000 \mathrm{~m}^{2}$ plot. Four plots of the same area were selected as controls, chosen randomly in the same field, at a distance beyond the influence of the pheromone. Due to the high insect pressure during the season, these plots were managed by the farmer who had to spread eight applications using a permetrine (Pounce ${ }^{\mathrm{R}}$ ) and methamidophos (MTD $600 \mathrm{SL}$, ANASAC, Chile) mixture in doses of $1 \mathrm{~L}$ and $200 \mathrm{~cm}^{3} \mathrm{ha}^{-1}$, respectively.

The damage caused by $P$. operculella was evaluated in all tubers of the samples. The number of undamaged tubers was counted and the percentage of moth damage was calculated in each treatment.

Data from the number of captures and the percentage of damaged tubers was analyzed using a variance analysis (ANOVA) with $5 \%$ probability and the means were compared by using a multiple comparison test with a Least Significant Difference (LSD). The statistical software used was SAS 8.0 for Windows.

\section{RESULTS AND DISCUSSION}

\section{Effect of trap density on captures}

P. operculella captures increased as the trap density increased (Table 1). Densities of 20 and 40 traps ha $^{-1}$ captured a significantly higher number $(\mathrm{P}<0.05)$ of males than the 10 traps ha ${ }^{-1}$ density. However, between the higher density traps (20 and 40 traps ha-1), the mean of males captured was not significantly different $(\mathrm{P} \geq 0.05)$. The mean of males captured per hectare indicates that approximately 


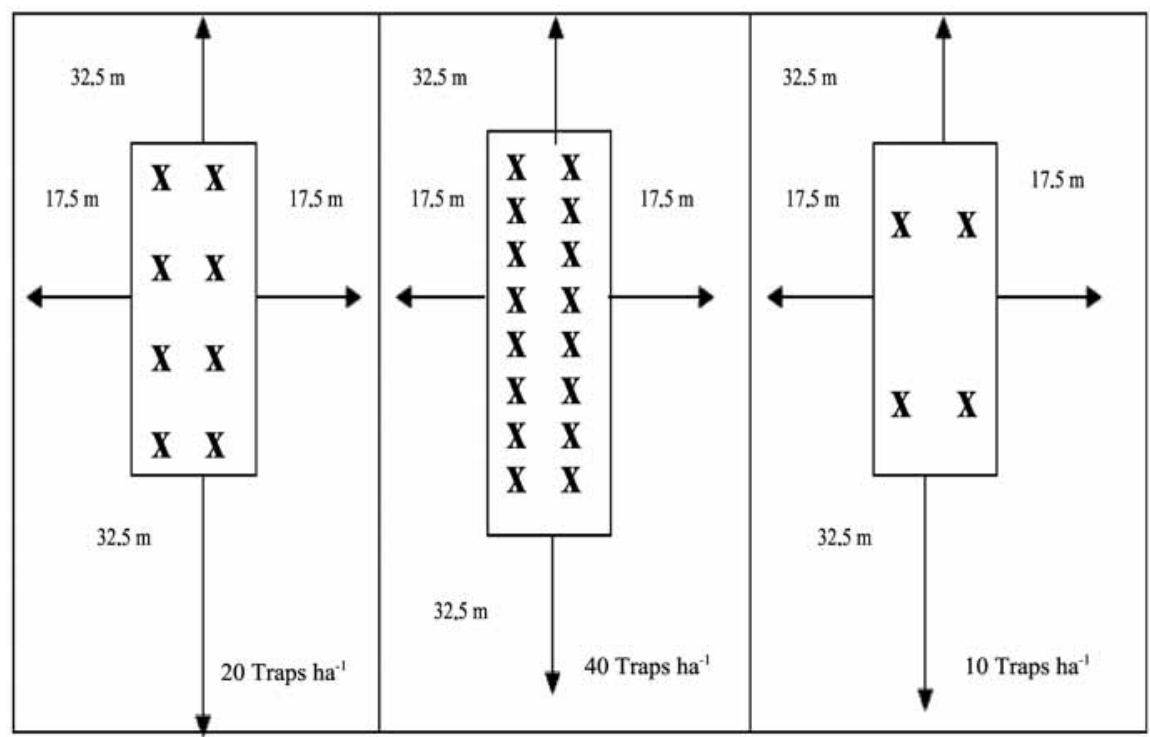

Figure 1. Distribution of treatments in trap density trial. El Romero 2004-2005.

108588 and 90173 males ha $^{-1}$ were captured with densities of 40 and 20 traps $h^{-1}$, respectively (Table 1 ). These results were higher than those obtained by Raman (1988) in Lima, Peru, who captured 92000 male P. operculella, but in $112 \mathrm{~d}$ with a density of 42 traps ha ${ }^{-1}$.

These differences could be due to various factors, such as the pressure of the male moth population in relation to its location, and trap characteristics (type, size, and pheromone dose per trap). Raman (1988) used a standard capsule from Centro Internacional de la Papa (CIP) (International Potato Center) with a 1 $\mathrm{mg}$ dose that was less attractive than the $0.2 \mathrm{mg}$ used in this trial according to the results of Larrain et al. (2007).

On the other hand, Ortu and Floris (1989) increased to 84 traps ha $^{-1}$, and observed a drastic reduction in captures, indicating that with this density, the sexual confusion of $P$. operculella could start to be effective.

\section{Tuber damage by moths}

Damage caused by $P$. operculella larvae in the tubers was significantly higher $(\mathrm{P}<0.05)$ with the control using insecticide treatment (51\% damaged tubers) than in the

Table 1. Mean of Phthorimaea operculella males captured in the 2004-2005 crop season.

\begin{tabular}{cc}
\hline $\begin{array}{l}\text { Treatment } \\
\left(\mathbf{N}^{\circ} \text { traps ha- }^{-1}\right)\end{array}$ & $\begin{array}{c}\text { Number of males captured } \\
\text { (64 days) }\end{array}$ \\
\hline 40 & $108588 \mathrm{a}$ \\
20 & $90173 \mathrm{a}$ \\
10 & $54864 \mathrm{~b}$ \\
Coefficient of variation, \% & 17.5 \\
\hline
\end{tabular}

plots with different densities of pheromone traps evaluated (Table 2).

In accordance with the results obtained by Araya et al. (2000), the potato tuber moths in La Serena, Chile, were less susceptible to methamidophos than populations evaluated in other regions in this country. However, no resistance was noted, so failure of the control could be due to the difficulty of insecticides to reach the insects once they are underground or inside the tubers, and also probably due to a higher mortality of the natural enemies of $P$. operculella caused by the synergetic effect of two broad-spectrum action insecticides.

On the other hand, in plots treated with pheromones, the highest rate of tuber damage (30\%) was obtained with the lowest density of 10 traps $\mathrm{ha}^{-1}$, and less captures. It is possible to emphasize that the damage was similar to that obtained in plots with 40 traps per hectare (25\%), where captures almost doubled compared to 10 traps $\mathrm{ha}^{-1}$ (Table 2). This aspect should be clarified with new studies where more data will be obtained to allow the analysis and establishment of a relation between the male captures and the tuber damage caused by the moth.

Raman (1988) observed minor damage that reached $19 \%$ with lower captures and a similar trap density, though factors such as varietal susceptibility, temperatures during the months of capture, pheromone dose per trap, and type of trap do not allow the comparison of these results.

In plots with moderate density of 20 traps ha- ${ }^{-1}$ with pheromones, minor damage was found with $18.3 \%$ of the tubers affected and significant differences $(\mathrm{P}<0.05)$ compared to the lesser density evaluated in 10 traps ha ${ }^{-1}$ (Table 2). 
Previous results indicate that the control of P. operculella with the insecticides most used in the Valle del Elqui, Chile, is inadequate since the number of tubers damaged was higher than 50\% with eight applications (Table 2). This entails a high economic cost for the farmer and generates environmental damage since insecticides are applied excessively, for example, methamidophos, which is one of the most toxic of the organic phosphate group and classified as an extremely dangerous toxicological category.

This is the first study that analyzes the potential use of mass trapping with sexual pheromones as a direct control method of $P$. operculella in Chile. The results reflect that the use of this technique constitutes a tool which can significantly reduce the number of males with a subsequent decrease in potato tuber moth larvae, resulting in a significantly lower tuber damage rate in the area within pheromone influence.

Table 2. Mean percentage of tubers damaged by Phthorimaea operculella in different pheromone trap densities and control (pesticide management).

\begin{tabular}{lc}
\hline $\begin{array}{l}\text { Treatment } \\
\left.\text { traps ha }^{-1}\right)\end{array}$ & $\begin{array}{c}\text { Mean of tuber damage } \\
\text { (\%) }\end{array}$ \\
\hline Control & $51 \mathrm{a}$ \\
10 & $30 \mathrm{~b}$ \\
20 & $18 \mathrm{c}$ \\
40 & $25 \mathrm{bc}$ \\
Coefficient of variation, \% & 19.4 \\
\hline
\end{tabular}

\section{CONCLUSIONS}

Twenty traps per hectare appear to be the most effective and convenient trap density to use in a potato tuber moth integrated management program. No significant difference was shown in male capture and tuber damage between this density and the higher trap density trials, therefore the lower density trap pattern proved to be as efficient and more economical.

\section{RESUMEN}

Efecto de la densidad de trampas de feromona en la captura masiva de machos de polilla de la papa, Phthorimaea operculella (Zeller) (Lepidoptera: Gelechiidae), y en el nivel de daño a los tubérculos. La polilla de la papa, Phthorimaea operculella (Zeller), es una de las plagas que causan mayor daño a la papa (Solanum tuberosum L.), tanto a los cultivos en campo como a los tubérculos almacenados, especialmente en zonas de climas cálidos y secos. Las larvas de este insecto se desarrollan en el follaje y tubérculos de papa causando pérdidas directas del producto a comercializar. La utilización de feromonas sintéticas, como una herramienta que interfiere con el apareamiento, ha sido ampliamente demostrada en innumerables especies de polillas y otros insectos. Con el fin de evaluar la efectividad de diferentes densidades de trampas de feromona en la captura de machos de $P$. operculella, para su futura utilización como técnica de trampeo masivo y consecuente disminución de la reproducción del insecto, se realizó un estudio durante la temporada 2004-2005, en el Valle del Elqui, Región de Coquimbo, Chile. Se evaluaron densidades de 10, $20 \mathrm{y}$ 40 trampas ha ${ }^{-1}$ con una carga de $0,2 \mathrm{mg}$ de feromona por trampa, utilizando trampas de agua con detergente para las capturas. Los resultados indican que la mayor captura de machos de polilla de la papa se obtiene con densidades de 20 y 40 trampas ha ${ }^{-1}$, encontrándose también una reducción significativa $(P<0,05)$ del daño en tubérculos en estos tratamientos comparados con el testigo convencional con aspersiones de insecticidas.

Palabras clave: papa, plagas, polilla de la papa, Phthorimaea operculella, capturas masivas, feromonas.

\section{LITERATURE CITED}

Adeesan, C., A.J. Tamhankar, and G.W. Rahalkar. 1969. Sex pheromone gland in the potato tuberworm moth, Phthorimaea operculella. Ann. Entomol. Soc. Am. 62:670-671.

Araya, J., M. Guzmán, y M.A. Guerrero. 2000. Verificación de susceptibilidad de las larvas de la polilla de la papa, Phthorimaea operculella (Zeller), a cuatro insecticidas. Inv. Agr. 20:53-60.

Athanassiou, C.G., N.G. Kavallieratos, S.F. Gakis, L.A. Kyrtsa, B.E. Mazomenos, and F.T. Gravanis. 2007. Influence of trap type, trap colour, and trapping location on the capture of the pine moth, Thaumetopoea pityocampa. Entomol. Exp. Appl. 122:117-123.

Athanassiou, C.G., N.G. Kavallieratos, F.T. Gravanis, N.A. Koukounitsas, and D.E. Rousou. 2002. Influence of trap type, pheromone quantity and trapping location, on the capture of the pink bollworm, Pectinophora gossypiella (Sounders) (Lepidoptera: Gelechiidae). Appl. Entomol. Zool. 37:385-391.

Athanassiou, C.G., N.G. Kavallieratos, E.Th. Kolokytha, and F.T. Gravanis. 2003a. Influence of the simultaneous use of pheromone sources on the capture of Pectinophora gossypiella (Sounders) (Lepidoptera: Gelechiidae) and Helicoverpa armigera (Hübner) (Lepidoptera: Noctuidae) on cotton. p. 1133-1141. In Proceedings of the Third World Cotton Research Conference, Cape Town, South Africa. 9-13 March 2003. Agricultural Research Council-Institute for Industrial Crops, Pretoria, South Africa. 
Athanassiou, C.G., N.G. Kavallieratos, and B.E. Mazomenos. 2004. Effect of trap type, trap color, trapping location and pheromone dispenser on captures of male Palpita unionalis (Hübner) (Lepidoptera: Pyralidae). J. Econ. Entomol. 97:321-329.

Athanassiou, C.G., N.G. Kavallieratos, and B.E. Mazomenos. 2005. Population dynamics of Palpita unionalis (Hubner) (Lepidoptera: Pyralidae) in central and northen Greece. IOBC/WPRS Bull. 28:117-120.

Athanassiou, C.G., N.G. Kavallieratos, N.E. Palyvos, and C.Th. Buchelos. 2003b. Evaluation of the multisurface trap on the capture of Ephestia kuehniella Zeller. Phytoparasitica 31:39-50.

Bacon, O.G., J.M. Seiber, and G. Kennedy. 1976. Evaluation of survey trapping techniques for potato tuberworm with chemical baited traps. J. Econ. Entomol. 69:569-572.

Cameron, P.G., G.P. Walter, A.R. Wallace, and P.J. Wigley. 2002. Movement of potato moth estimated by markrecapture experiments. N.Z. Plant Protect. 55:177181.

El-Sayed, A.M., D.M. Suckling, C.H. Wearing, and J.A. Byers. 2006. Potential of mass trapping for long-term pest management and eradication of invasive species. J. Econ. Entomol. 99:1550-1564.

Fouda, H.G., J.N. Seiber, and O.G. Bacon. 1975. A potent sex attract for the potato tuberworm moth. J. Econ. Entomol. 68:423-427.

Kumral, N.A., B. Kovanci, and B. Akbudak. 2005. Pheromone trap catches of the olive moth, Prays oleae (Bern.) (Lep., Plutellidae) in relation to olive phenology and degree-day models. J. Appl. Entomol. 129:375-381.

Larraín, P., M. Guillon, J. Kalazich, F. Graña, y C. Vásquez. 2007. Efectividad de distintas dosis de feromona sexual de Phthorimaea operculella (Zeller) (Lepidoptera: Gelechiidae) en la captura de machos de polilla. Agric. Téc. (Chile) 67:431-436.
Ortu, S., and I. Floris. 1989. Preliminary study on the control of Phthorimaea operculella (Zeller) (Lepidoptera: Gelechiidae) on potatoes crops in Sardinia. Difesa-delle-Piante 12:1-2, 81-88.

Persoons, C.J., S. Voerman, P.E.J. Verwiel, F.J. Ritter, W.J. Nooijen, and A.K. Minks. 1976. Sex pheromone of the potato tuberworm moth Phthorimaea operculella: isolation, identification and field evaluation. Entomol. Exp. Appl. 20:289-300.

Raman, K.V. 1982. Field trials with the sex pheromone of the potato tuberworm (Lepidoptera: Gelechiidae). Environ. Entomol. 11:367-370.

Raman, K.V. 1984. Evaluation of a synthetic sex pheromone funnel trap for potato tuberworm moths (Lepidoptera: Gelechiidae). Environ. Entomol. 13:6164.

Raman, K.V. 1988. Control of potato tuber moth Phthorimaea operculella with sex pheromones in Perú. Agric. Ecosyst. Environ. 21:85-89.

Roelofs, W.L., J.P. Kochansky, and R.T. Cardé. 1975. Sex pheromone of the potato tuberworm moth Phthorimaea operculella. Life Sci. 17:699-706.

Salas, J., A. Parra, y C. Álvarez. 1985. Evaluación preliminar de la feromona sexual sintética del minador grande de la hoja del tomate Phthorimaea operculella en la captura de machos. Agron. Trop. 35:139-144.

Voerman, S., and G.H.L. Rothschild. 1978. Synthesis of the potato tuberworm moth Phthorimaea operculella (Zeller) (Lepidoptera: Gelechiidae): and field experience with them. J. Chem. Ecol. 4:531-542.

Voerman, S., A.K. Minks, and C.J. Persoons. 1977. Elucidation of the sex pheromone systems of the potato tuber worm moth Phthorimaea operculella (Zeller) (Lepidoptera: Gelechiidae): a short review. Potato Res. 20:123-126.

Yamoaka, R., H. Fuakami, and S. Ischii. 1976. Isolation and identification of the female sex pheromone of the potato tuberworm moth Phthorimaea operculella (Zeller). Agric. Biol. Chem. 40:1971-1977. 